\title{
Sindicatos e Cordões Industriais: uma reflexão em torno do histórico da organização operária chilena e da sua mobilização revolucionária
}

\author{
Márcia C. de O. Cury*
}

Resumo: O presente artigo propõe uma reflexão em torno de importantes elementos que compunham as formas de organização e de mobilização nas experiências dos trabalhadores chilenos. Configurações que foram ampliadas e intensificadas durante o governo da Unidade Popular (1970-1973). O intuito é demonstrar que tais experiências permitiram o desenvolvimento de modelos de organização e de atuação política pautados na solidariedade, como os chamados Cordones Industriales.

Palavras-chave: Sindicalismo — Chile — Cordones industriales

Abstract: This paper proposes a reflection on the important elements that made the forms of organization and mobilization on the experiences of Chilean workers. Settings that were expanded and intensified during the Popular Unity government (1970-1973). The aim is to demonstrate that such experiments allowed the development models of organization and political action guided by solidarity, as called Cordones Industriales.

Keywords: Unionism —Chile — Cordones industriales

\section{Apresentação}

Neste ano, em que se completam quatro décadas do golpe militar que pôs fim ao governo de Salvador Allende, certamente ainda há muito o que ser discutido em torno daquela experiência. Desde a vitória da Unidade Popular (UP), em setembro de 1970, a "experiência chilena" vem sendo analisada por um número importante de grupos políticos e estudiosos no mundo inteiro. Mas, um aspecto fundamental a ser colocado nesse debate é o grande envolvimento dos trabalhadores chilenos, carregados das suas paixões e experiências políticas, em torno do governo que propunha a construção do socialismo sem romper com os mecanismos institucionais.

* Historiadora e Doutora em Ciência Política pela Unicamp. Professora do Centro Universitário Jorge Amado, Salvador-BA. Pesquisa financiada pela FAPESP. Contato: curybr@yahoo.com.br 
Inserido nessa proposta, o presente artigo propõe uma reflexão em torno dos elementos que compõem a história de organização e de militância dos trabalhadores chilenos, que desembocariam em diversos modelos alternativos de mobilização no período revolucionário, especialmente os chamados Cordones Industriales. ${ }^{1} \mathrm{O}$ objetivo central do artigo é demonstrar que o histórico de organização e das relações entre os trabalhadores no âmbito das empresas e das suas organizações de classe se constitui de elementos fundamentais para a compreensão daquele modelo de mobilização em torno do projeto socialista. Para tanto, serão abordadas diferentes conjunturas da história chilena no século XX que nos permitirão identificar os aspectos mais importantes do desenvolvimento da organização operária.

Para analisar as ações dos movimentos sociais, dos sindicatos e das demais organizações dos trabalhadores, como os Cordões Industriais, foram examinados documentos como revistas e panfletos produzidos pela esquerda e por parte do movimento operário. Os documentos presentes no Ministério do Trabalho do Chile possibilitaram uma aproximação aos conflitos no cotidiano do trabalho, antes e durante o período da UP. Por meio deles foi possível apreender muitos elementos das normas, das relações de trabalho e da prática política dos trabalhadores. Analisei registros dos processos referentes a greves, piquetes e ocupações de fábrica, bem como os registros das relações com o Estado. Os demais documentos consistem em publicações partidárias, pronunciamentos, programas políticos e entrevistas dos líderes políticos do período. Além disso, utilizamos o documentário de Patrício Guzmán, A batalha do Chile, que, com imagens do período, retrata também o dia a dia dos trabalhadores nas suas organizações e cotidiano dos conflitos sociais.

Os relatos orais estão entre as principais fontes utilizadas. As entrevistas foram formuladas de forma a se conhecer mais sobre a trajetória de vida de cada um deles, buscando as origens, as influências políticas, as experiências no trabalho e na vida comunitária. Dessa maneira, foi possível compreender melhor as suas experiências cotidianas e políticas, as formas com que vivenciaram a organização operária antes e durante o governo da Unidade Popular. Os operários escolhidos estão entre aqueles que vivenciaram o processo de transformação na organização operária nas fábricas, marcado por uma maior radicalização política, e que estiveram vinculados de alguma maneira aos Cordões Industriais. O reconhecimento dos riscos que implica o trabalho com as fontes orais exigiu a sua problematização com as outras fontes e especialmente com relatos da época.

\section{O histórico sindical}

A experiência da Unidade Popular não pode ser compreendida sem que se considere as ações das bases sociais do país nos seus próprios termos, que, no enfrentamento com as bases do Estado capitalista, trouxeram os elementos mais significativos daquele processo. Mas, pensar na mobilização social durante a "experiência chilena" requer a análise do movimento dos trabalhadores para além daquela conjuntura, pois, se a originalidade do processo esteve na forte mobilização popular, não se pode afirmar que a organização dos trabalhadores se originou

1 Os Cordões Industriais podem ser caracterizados como setores industriais que congregavam fábricas de diferentes ramos produtivos e que, por necessidade dos empresários e do tipo de industrialização desenvolvida no Chile, foram criados em áreas de fácil acesso, ligados por vias expressas, para facilitar tanto a chegada de matéria-prima quanto o escoamento da produção. A importância dessas áreas durante o governo da Unidade Popular (UP) esteve na articulação política dos sindicatos das empresas estabelecidas nesses locais. 
ou assumiu características totalmente novas devido à vitória eleitoral da coalizão liderada pela esquerda.

Mais do que o surgimento de novas formas de organização dos trabalhadores, o período da Unidade Popular permitiu que se expressassem fortemente em torno daquele projeto transformador a identidade e os diversos elementos constituintes das formas de mobilização dos trabalhadores, oriundos do seu próprio repertório de lutas. Muitos dos elementos presentes na organização operária podem ser melhor compreendidos se refletirmos sobre o seu histórico de organização.

Dedicarei este espaço para uma reflexão em torno da organização e das práticas sindicais. Sobre esse aspecto, é importante atentar, por exemplo, para a forma como se deu a inserção e a participação dos diferentes grupos políticos no processo de modernização do Estado chileno, a partir dos anos trinta, e a consequente institucionalização do conflito social. Esse processo influenciou diretamente a configuração e o desenvolvimento dos diferentes grupos políticos ao longo das décadas, especialmente da esquerda e dos movimentos sociais. Inserida nessa questão, pode-se compreender aspectos essenciais do desenvolvimento do movimento operário chileno e das estruturas geradas na sua formação, e abordar os desdobramentos desse processo que desembocariam em perfis e conflitos que se refletiriam ainda no governo da Unidade Popular.

Merece destaque a regulação estatal das relações trabalhistas, que gerou um modelo de organização que acarretaria, por um lado, a descentralização do movimento operário, mas não a sua fragilização, já que acabou configurando uma representação de significativa legitimidade entre os trabalhadores. Essa estrutura viria a exercer um impacto fundamental na mobilização do movimento operário nos anos posteriores, principalmente, durante a Unidade Popular.

\section{O Estado e os trabalhadores}

Dentre as medidas de integração e de controle da ordem político-social, os atores políticos adotaram reajustes nos mecanismos do Estado. Para nós, tem especial importância medidas aplicadas às relações de trabalho a partir das legislações de 1924 e 1931. É importante retomar questões referentes às regras que passaram a guiar as relações de trabalho e o novo papel do Estado neste período, pois elas servirão para refletirmos sobre a dinâmica alcançada pelo movimento operário nas décadas seguintes e durante o governo da Unidade Popular.

As transformações que desembocaram na "institucionalização dos conflitos", com a participação da esquerda na política institucional e o reconhecimento e legalidade do sindicalismo como meio de expressão das demandas operárias, em geral, são encaradas como mecanismos que levaram à subordinação dos movimentos de representação popular e ao arrefecimento do conflito de classes aberto. ${ }^{2}$

De acordo com Angell, a preocupação dos intelectuais com a questão social, entre eles ativistas políticos e dirigentes partidários, levou-os a desenvolver medidas de regulamentação, mais por temor ao radicalismo do movimento operário existente e tentando eliminar as influências radicais, promovendo a formação de sindicatos controlados pelo Estado e pelos patrões. ${ }^{3}$ Esses intelectuais entendiam

2 SALAZAR, Gabriel. Del poder constituyente de asalariados e intelectuales. Chile, siglos XX y XXI. Santiago: LOM Ediciones, 2009.

3 ANGELL, Alan. Partidos politicos y movimiento obrero en Chile. México: Ediciones Era, 1974, p. 69. 
que havia a necessidade de um código trabalhista para restringir e conter as atividades dos operários organizados, liderados, principalmente, por comunistas e anarco-sindicalistas, que cresciam, radicalizavam-se e explicitavam o conflito social com a crescente violência no choque com as forças repressivas.

Com a promulgação da legislação trabalhista, em 1924, o Estado passou a intervir diretamente nos conflitos trabalhistas e a propiciar importantes modificações na organização operária, quando passou a reconhecê-la por meio da legalização do sindicalismo, a estabelecer controle sobre ela e a limitar seus objetivos e suas normas de funcionamento. Esse sistema estabelecia sete leis relativas a contrato de trabalho, sistema de seguro de doença, invalidez e acidentes, conciliação e arbitragem, sindicatos, cooperativas. Ações que, segundo as palavras do então presidente da República, Arturo Alessandri Palma, indicavam que havia chegado “o momento de ceder algo para manter a paz e a ordem", entendido, então, como "o único remédio eficaz para evitar a revolução". ${ }^{4}$

Evidentemente, a fase inicial de implementação do novo código trabalhista marcou um período de debates entre as lideranças sindicais e políticas no sentido da sua recusa ou aceitação para garantir benefícios e proteção governamental e para estender a influência dos sindicatos onde estes ainda não haviam conquistado adesão. Concebida como uma solução para a "questão social" provocada pela militância de trabalhadores, o sistema chileno oferecia reconhecimento trabalhista legal em troca de maior controle estatal, enquanto trocava coerção por integração ao sistema da ordem como uma estratégia de elite de controle social.

A conciliação e a arbitragem não eram elementos da cultura de relações entre patrões e trabalhadores, ao menos não como prática institucionalizada e regular. Ao longo do século XIX, em diversos conflitos, as autoridades locais ou regionais haviam mediado os conflitos com maior ou menor êxito, mas isso se deu como iniciativas isoladas que não constituíam um sistema oficial ao qual as partes pudessem recorrer regularmente para solucionar suas diferenças. Os conflitos entre capital e trabalho no último terço do século XIX eram caracterizados pela inexistência de leis e de normas que os regulassem. A conciliação e a arbitragem dependiam do acordo entre trabalhadores, empresários e funcionários provinciais, municipais, policiais ou militares.

Segundo Grez Toso, a primeira reação de trabalhadores grevistas era rejeitar a arbitragem, especialmente depois de vivenciarem tantas experiências de repressão. Ao mesmo tempo, com a recusa dos patrões em negociar, muitos setores de trabalhadores viram nesses mecanismos um escudo protetor, especialmente quando tinham que enfrentar capitalistas intransigentes. Esses mecanismos foram se generalizando a tal ponto que, até o Centenário da Independência, já constituíam em uma prática relativamente difundida, ainda que sem obrigatoriedade legal, mas se generalizavam de forma a adquirir "cor de direito". ${ }^{5}$

4 Trecho de uma carta de Arturo Alessandri Palma citado por Crisóstomo Pizarro. Esta legislação garantia o direito à organização sindical e à greve, o descanso dominical, a indenização por acidentes de trabalho, o seguro obrigatório para os operários e a limitação da jornada a oito horas diárias, respondendo efetivamente às atividades grevistas precedentes. In: PIZARRO, Crisóstomo. Rol de los sindicatos en Chile. Estudios Cieplan, n.22, marzo-1978, p. 9.

5 Neste artigo, o autor faz uma importante análise sobre a difusão da ideia de direito entre os trabalhadores. Aqui ele se remete à perspectiva do E. P. Thompson, dos costumes enquanto uma prática que adquiria "cor de privilégio ou direito" ou "retórica de legitimação de quase todo uso, prática ou direito reclamado". GREZ TOSO, Sergio. Autonomia o escudo protector? El movimiento obrero y popular y los mecanismos de conciliación y arbitraje (Chile 1900-1924). Cyber Humanitates, 41, Summer, 2007. 
Com o acirramento dos conflitos sociais nos anos de 1920, o presidente Arturo Alessandri se tornou o maior defensor e propagandista da regulação das relações trabalhistas, aproveitando-se da sua imagem positiva no mundo popular. Depois de um longo período de resistência e repressão, até os anos de 1930, a maior parte do movimento trabalhista aceitou gradativamente a troca implícita nas leis trabalhistas e começou a trabalhar com elas. Isso se consolidou durante o governo da Frente Popular. O fator determinante para se generalizar a mudança na relação do movimento operário com as propostas de mediação estatal foi a mudança de atitude do Partido Comunista ao se iniciar o período da frente antifascista. ${ }^{6}$

\section{A Frente Popular e o seu significado}

O processo da Frente Popular (1938-1941) marcou a cristalização da incidência das demandas sociais sobre o Estado - principalmente com a significativa representação dos setores populares a partir da participação da esquerda nos espaços políticos - e foi determinante para a fundação do compartilhamento de projetos políticos entre os trabalhadores e a esquerda. ${ }^{7}$ Essa conjuntura, que pode ser visualizada como um momento de institucionalização dos conflitos, não significou o fim da autonomia das lutas operárias. Elas adquiriram novas formas, mas mantiveram a complexidade das suas características e manifestações, inclusive com o questionamento às regras institucionais.

Assim, o movimento operário da década de 1930 foi progressivamente se constituindo com novos perfis sociais e políticos, abarcando o proletariado urbano moderno, sem perder sua ancoragem na mineração, que também se modernizou, principalmente no cobre. E sua base passou a se apoiar principalmente no sindicalismo legal, atingindo crescentes graus de institucionalização, com orientações ideológicas expressadas principalmente por meio dos partidos comunista e socialista. Esse processo se cristalizou com a vitória da coalizão da Frente Popular, que marcou o início de uma nova fase do movimento operário. Nesse momento, o movimento encontrava-se unificado na Confederación de Trabajadores de Chile $(\mathrm{CTCH})$, que teve importante papel de suporte à Frente Popular e representação em órgãos estatais, como a Corporación de Fomento (CORFO). ${ }^{8}$

Pela primeira vez na história política chilena houve uma aliança política entre o movimento operário, os partidos de esquerda como seus representantes e grupos de centro em defesa de um programa governamental, na medida em que este representava uma possibilidade de atendimento das demandas essenciais dos trabalhadores. Esse apoio estava condicionado à realização das reformas prometidas no programa de 1938. Assim como na história brasileira durante o governo

6 ANGELL, A. op. cit., 1974, p. 70.

7 A noção de projetos políticos é tomada aqui como "os conjuntos de crenças, interesses, representações do que deve ser a vida em sociedade, que orientam a ação política. Esta noção não se reduz a estratégias de atuação política no sentido estrito, nem a formulações sistematizadas e abrangentes, como os projetos partidários. Esta concepção expressa significados que integram matrizes culturais mais amplas e permite apreender a multiplicidade de sujeitos políticos e das suas diferentes formas de ação política”. DAGNINO, Evelina; OLVERA, Alberto J.; PANFICHI, Aldo. Para uma outra leitura da disputa pela construção democrática na América Latina. In: DAGNINO, Evelina; OLVERA, Alberto J.; PANFICHI, Aldo. A disputa pela construção democrática na América Latina. São Paulo: Paz e Terra; Campinas: UNICAMP, 2006.

8 O Estado criou a CORFO (Corporación de Fomento de la Producción), organismo voltado ao estímulo do desenvolvimento. $O$ órgão visava à concessão de créditos para atividades já existentes, créditos para pesquisas e experimentação de novos processos produtivos, para a exploração mineral em novas áreas e para a preparação técnica de pessoal. 
de Getúlio Vargas, nota-se no Chile a incorporação e os privilégios de alguns sindicatos. A esse respeito, é sugestiva a aliança existente entre a FP e a Confederação dos Trabalhadores do Chile, que desde 1936 reunia um número importante de sindicatos e organizações operárias, especialmente de setores estratégicos e de grandes empresas.

De fato, esse processo exerceu efeitos significativos ao longo da trajetória do movimento operário e, principalmente, da esquerda ao longo do século XX, incidindo sobre os rumos que o movimento tomaria até 1973. Esse período que cristaliza o modelo de institucionalização dos conflitos tinha a centralidade do papel do Estado como fator de coesão e elemento comum a todos os discursos e projetos políticos em disputa, da direita à esquerda da cena política nacional.

As análises realizadas pela historiografia sobre o período convergem sobre o significado dos rumos adotados a partir da crise oligárquica no país, identificando a consolidação de um processo de desenvolvimento do capitalismo, com base na defesa de um regime de democracia liberal representativa, com a participação de diferentes setores políticos e com um modelo de industrialização e de integração social regido pelo Estado. A consolidação desse modelo foi a marca do governo da Frente Popular e dos governos que a seguiram até a década de $1950 .{ }^{9}$

A relação dos trabalhadores com o Estado sofreria uma guinada fundamental. A CTCH se envolveu diretamente na campanha eleitoral da Frente Popular, oferecendo respaldo e uma atitude colaboracionista com o governo, participando diretamente da gestão governamental. O Secretário Geral da Confederação foi conselheiro da CORFO, e a CTCH designava conselheiros a outros órgãos, como a Caixa de Habitação, ao Conselho de Subsistência e Preços, à Defesa Civil e ao denominado Conselho Superior do Trabalho. Desde a campanha da coalizão, portanto, alterou-se a postura do movimento dos trabalhadores, que passava a se basear na valorização da legislação social, no contexto de uma relação de compromisso com o novo governo. A década de 1930 viveu o auge da sindicalização legal. Ao final de 1939, havia 593 sindicatos industriais, com mais de 105 mil sócios. Praticamente todo o movimento sindical anterior à legislação se legalizou. ${ }^{10}$

Com a magnitude dos problemas econômicos e sociais sofridos diretamente pelos trabalhadores, a ausência de canais de atendimento das suas demandas e de pressão sobre o Estado até a criação da nova legislação, e com a importância adquirida pelo movimento operário enquanto sujeito social em meio aos projetos políticos que se discutiam no país, aquele contexto se apresentava às organizações dos trabalhadores como um momento favorável para conquistar seu espaço nas lutas institucionais, até então dominadas pela oligarquia nacional.

Considerando as condições históricas, a crescente institucionalização da ação operária consistiu numa construção política eficaz para colocarem na pauta do debate público questões urgentes do conflito entre capital e trabalho, e assumirem espaços que garantiram maior democratização política e social. Ao mesmo tempo, esse processo marcou o início das contradições do movimento operário organizado que se desenvolveu ao longo do século, dando origem à Central Única dos Trabalhadores do Chile (CUT), em 1957.

9 Cf.: AGGIO, Alberto. Frente popular, radicalismo e revolução passiva no Chile. São Paulo: Annablume, 1999.

10 Entre os anos de 1927 e 1931 se organizaram cerca de 85 sindicatos industriais com 27 mil sócios, nos setores econômicos mais importantes do país: salitre, cobre, carvão, fábricas metalúrgicas, têxteis etc. BARRERA, Manuel. Perspectiva histórica de la huelga obrera en Chile. Cuadernos de la Realidad Nacional, 9, septiembre de 1971, p. 138. 


\section{O impacto da regulação das relações trabalhistas}

A incorporação dos temas e conflitos trabalhistas aos mecanismos do Estado no Chile foi objeto de investigação, especialmente no que se refere à estrutura criada e à influência exercida sobre o conjunto do movimento operário, bem como ao significado das relações sindicais com os partidos políticos do país. O que buscarei demonstrar aqui é que a forte relação estabelecida com a esquerda partidária e a formação de uma estrutura diferenciada dentro do sindicalismo forjaram condições muito específicas e importantes para a configuração de uma forte identificação entre os trabalhadores e suas entidades representativas.

Apesar de estatísticas impressionantes indicarem um grande número de trabalhadores sindicalizados, diferentes autores apontam para a existência de uma importante fragilidade estrutural do movimento sindical nacional dentro de um sistema complexo de relações trabalhistas. ${ }^{11} \mathrm{Na}$ prática sindical, entre as principais medidas estabelecidas que teriam acarretado a fragilidade do movimento estariam táticas bastante restritivas quanto ao alcance e à autonomia das organizações dos trabalhadores. Dentre as suas principais características organizativas, vale lembrar que os sindicatos eram organizados por empresa, e não por setor produtivo ou categoria de trabalhadores. A partir dessa regulamentação, proibia-se, por exemplo, a organização de sindicatos em fábricas que tivessem menos de 25 trabalhadores, uma restrição importante se considerarmos que a maioria das empresas no país era constituída por estabelecimentos de pequeno porte.

Uma vez que o sindicato era um órgão representativo dos trabalhadores de uma empresa, proibia-se o seu envolvimento em negociações coletivas do setor ou em categoria de outro estabelecimento, ou a convocação de greves solidárias. A maioria dos operários estava organizada em "sindicatos industriais", denominação dada aos sindicatos formados por operários, cuja filiação era obrigatória sempre que em qualquer estabelecimento de pelo menos 25 trabalhadores houvesse um voto de pelo menos $55 \%$ deles favorável à organização de um sindicato. Poderia haver um sindicato por estabelecimento e não era permitido a eles formar federações com outros sindicatos com o fim de realizar negociações coletivas. ${ }^{12}$

Além disso, o Código trabalhista estabeleceu a distinção legal entre os trabaIhadores, classificando-os entre "operários" e "empregados", institucionalizando a sua divisão por meio da diferenciação entre o ofício "manual" e o "intelectual", a diferença salarial e a discriminação social, ocasionando, se não o conflito, a dificuldade para estabelecer uma unidade de ação. Na indústria manufatureira, os empregados, em geral funcionários administrativos, chefes ou profissionais com formação técnica recebiam salários médios três vezes maiores do que os dos operários, com ajustes automáticos para cobrir a alta no custo de vida. Além disso, nos serviços sociais e em outros benefícios (que compunham uma parte importante dos salários e das aposentadorias) também se favorecia ao empregado.

A formação de federações entre os sindicatos industriais estava restrita a fins educativos e assistencialistas, e não à luta por direitos econômicos e sociais dos

11 Os principais autores que defendem a tese da fragilidade do sindicalismo chileno são ANGELL, Alan, op. cit., 1974 e BARRERA, Manuel. El sindicato industrial como instrumento de lucha de la classe obrera chilena. Universidad de Chile, Instituto de Economía y Planificación, Santiago, 1971.

12 A maioria dos sindicatos chilenos era pequena: em 1968, o tamanho médio dos sindicatos de empresa era de 155 membros; $63 \%$ de todos os sindicatos tinham menos de 100 membros; só 26 sindicatos tinham mais de mil membros. O sindicato industrial local, ou seja, por fábrica, consistiu na espinha dorsal do movimento sindical chileno. 
trabalhadores. Essa legislação gerou a dispersão do movimento operário sindical e a proliferação de pequenos núcleos organizacionais, o que para Manuel Barrera significou a cristalização da orientação de colaboração entre capital e trabalho, na medida em que dificultava a realização de atividades que quebrassem a disciplina e a ordem no trabalho.

O novo Código Trabalhista de 1931 outorgou ao Estado a autoridade para regular as relações de trabalho e para assegurar a democracia sindical, colocando-o como árbitro dos conflitos entre trabalhadores e patrões. O reconhecimento do Estado passou a ser o meio da legitimidade sindical. Os inspetores trabalhistas supervisionavam os assuntos sindicais e as mesas de mediação estatal. Assim, o direito à greve estava sujeito à regulação do Estado, cujos funcionários garantiam ou negavam sua legalidade.

O Estado também exercia certo controle sobre os sindicatos em determinados aspectos, como, por exemplo, por meio da participação nas reuniões sindicais, da revisão de documentação e do exercício do controle financeiro sobre as organizações. Financeiramente, foi imposta uma série de limitações à estruturação dos sindicatos, na medida em que os proibiam de ter fundos de resistência para o caso de declarar greves. $\mathrm{E}$, ainda que muitos conseguissem burlar essa lei, era difícil, já que o Estado controlava com muita precisão os assuntos financeiros dos sindicatos. O orçamento dessas agremiações tinha que ser submetido a inspetores do trabalho locais, e os tesoureiros só podiam ter às mãos uma quantidade bem pequena de dinheiro; o restante deveria ser depositado em uma conta bancária supervisionada pelo governo.

Esse poder do Estado, por vezes, submetia os sindicatos a ações de funcionários e políticos corruptos ou conservadores que atuavam de maneira a fazer vistas grossas para a burlagem do Código do Trabalho e a assegurar o controle exercido pelos empresários. São inúmeras as denúncias que encontramos nos registros da Direção do Trabalho, órgão do Ministério do Trabalho responsável pela fiscalização das relações trabalhistas, apontando a conivência de inspetores e diretores com os abusos patronais devido a relações pessoais de amizade, compadrio ou sociedades com os empresários.

Em uma das cartas encaminhadas à Direção do Trabalho, na década de sessenta, o trabalhador de um posto de gasolina afirmava que havia sido destratado pelo patrão, que ele o teria ameaçado dizendo que era compadre do inspetor do trabalho da região, e que, portanto, sua queixa não resultaria em nada. Também havia casos em que o inspetor responsável por uma determinada região ou o próprio Ministro do Trabalho era sócio de empresas citadas. ${ }^{13}$ As queixas apresentadas à Direção do Trabalho envolvem muitos casos de perseguição a sindicalistas, demissões sem justificativas, abusos, ameaças. Além da ameaça de demissão, há casos de intimidação por parte do empregador de "fazer com que ele não encontrasse mais emprego se reclamasse demais". ${ }^{14}$ Além disso, o código trabalhista não estabelecia nenhuma sanção para os patrões que não cumprissem com seu ordenamento, enquanto que os sindicatos que não se ajustassem a eles estavam seriamente ameaçados por um bom número de penalidades.

Dessa forma, os sindicatos dificilmente conseguiam sustentar greves prolongadas, agindo geralmente por meio de uma greve curta, às vezes violenta, acompanhada frequentemente da ocupação da fábrica, que podemos descrever como

13 Dirección del Trabajo, Providencias, Volumen 2244. Osorno, 27 de octubre de 1965.

14 Dirección del Trabajo, Providencias, Volumen 2327. Antofagasta, 22 de julio de 1965. 
uma ocupação ou um piquete no espaço de trabalho, prática recorrentemente utilizada. Não havia meios para sustentar uma ação prolongada. ${ }^{15}$ Quando necessário, os sindicatos recorriam à assistência de um partido político.

Com base nessas características, as análises de Angell e de Barrera convergem para a avaliação das consequências negativas da estrutura do movimento sindical chileno no que diz respeito à ausência de uma estrutura mais unificada, e das dificuldades no manejo de um movimento sindical composto de um número elevado de pequenas unidades, diferentemente de um composto de federações burocráticas grandes. A estrutura regulamentada pelo Estado, que visava fragilizar o movimento sindical, fortaleceu a ideia sobre o movimento operário de que a criação de uma estrutura sindical que não possibilitava a formação de grandes sindicatos por categorias de trabalhadores, fragmentando-os em pequenos núcleos por empresa, teria contribuído para o enfraquecimento do movimento operário do país.

Mesmo considerando a participação popular no governo socialista como a característica mais criativa daquele processo, ao relacionar o governo popular com o movimento operário, Gaudichaud traz elementos de convergência com aquelas análises da historiografia a respeito do movimento operário do país, que o concebe como frágil e dependente dos partidos. Assim, para o autor, a história do movimento operário chileno e das lutas sindicais foi marcada por uma oscilação entre períodos de autonomia, de independência e de subordinação em relação às instituições do Estado e aos partidos políticos. ${ }^{16}$

Defendo, no entanto, que se por um lado essa conformação da organização sindical dificultou a formação de grandes estruturas de unificação sindical, fragilizando-a institucionalmente, por outro, acabou contribuindo para a gestação de características muito particulares que fortaleceram a identificação e a legitimidade dos sindicatos industriais entre os trabalhadores, comum processo de consolidação de relações solidárias entre eles. E que a expressão máxima dessa organicidade se deu nos anos da Unidade Popular, com várias manifestações classistas em defesa dos seus direitos e da construção de uma nova ordem a partir da sua articulação nas bases.

Evidentemente, quando se afirma que a vitória da Frente Popular, em 1938, marcou a cristalização de um novo período na história do movimento operário, isso não deve significar que esse evento constituiu um processo de completa ruptura do movimento operário com as suas tradições radicais de luta, de ação direta, de contestação da ordem e com a sua identidade classista. A partir da década de 1930, na qual se assiste à reestruturação econômica e social do país, o que se observa nos movimentos populares são dinâmicas distintas, de acordo com o setor e com a vinculação ideológica, fluxos e refluxos diante das ações governamentais, seja no sentido da sua política de integração ou numa direção repressiva.

Com base nesses estudos sobre a organização do movimento operário e as suas relações com o Estado, é possível ter uma dimensão mais abrangente das transformações ocorridas na dinâmica das organizações dos trabalhadores e dos espaços institucionais ocupados por elas, levando-nos a visualizar conquistas e limites impostos à atuação do movimento operário na contestação da ordem. No entanto, para este estudo, foi fundamental recorrer a uma análise empírica que possibilitasse compreender como se deu na prática a aplicação dessa regulamenta-

15 ANGELL, A., op. cit., 1974, p. 72.

16 GAUDICHAUD, Franck. Poder Popular y Cordones Industriales. Testimonios sobre el movimiento popular urbano, 1970-1973. Santiago: LOM Ediciones, 2004, p. 104. 
ção e o seu real impacto sobre o cotidiano dos trabalhadores e sobre a formação da sua identidade.

Assim, é possível observar que a institucionalização dos conflitos não impediu o avanço organizativo e as expressões legítimas da classe trabalhadora chilena ao longo das décadas. Se, por um lado, não anseio sair em defesa de um legado que foi restritivo e contraditório da legislação sindical e da integração política, por outro, não é prudente incidirmos no extremo oposto de enxergar o período anterior de forma idealizada, como se fosse "o reino da autonomia da classe trabaIhadora", como afirma Hélio da Costa a respeito da classe trabalhadora no Brasil.. ${ }^{17}$ Nesta análise procuro observar o avanço da mobilização dos trabalhadores ao longo das décadas, que permitiu a vivência de diversas experiências na formação de organizações, o aprendizado político e a consolidação de laços que se estenderam e permaneceram, até culminarem em formas diferenciadas de organização durante o governo popular.

\section{Relações, condições de trabalho e política}

Uma das particularidades que se pode observar no movimento sindicalista chileno é que ele era suficientemente extenso e, o que é mais importante, consideravelmente representativo da força operária ativa. É certo que, com a complexidade que assumiu a estrutura sindical do país, é muito difícil estabelecer modelos precisos a respeito da dinâmica de um movimento, composto de muitos sindicatos pequenos, o que favorece situações mais diversas, como, por exemplo, inúmeras situações em que a organização era controlada pelo patronato. Os estabelecimentos muito pequenos podiam favorecer com frequência um tipo de relação que dificultava a rebelião dos empregados contra os patrões, que contavam também com a conivência do Estado.

Ainda que na década de 1930 os trabalhadores tenham assegurado uma maior vigilância do Estado sobre as relações trabalhistas e sobre a aplicação dos seus direitos, são muitos os casos de permanência da burlagem das leis e de desmandos patronais ao longo dos anos. ${ }^{18} \mathrm{O}$ cotidiano fabril revela aspectos das relações de trabalho que nem sempre eram atingidos pela regulação do Estado, ignorada pela conduta autoritária de gestores e patrões. Se em empresas situadas na capital as condições mínimas ainda não eram asseguradas, nas minas, o maior poder patronal e o isolamento contribuíam para o agravamento da situação. O exemplo do operário mineiro Inocente Santo é bastante elucidativo. Em 1941, ele construía instalações para uma empresa de eletricidade do país em meio à neve da Cordilheira dos Andes. O ex-operário ainda carrega no corpo as consequências do trabalho, devido às condições a que era submetido na época:

Eu trabalhei muito na cordilheira, na neve, por isso estou doente. [Vivíamos] em acampamentos, acampamentos insalubres. Tinha que lutar para que fizessem acampamentos para poder dormir, não como seres humanos, porque no acampamento tem só tábuas. A neve entrava pelas

17 COSTA, Hélio da. Em busca da memória.Comissão de fábrica, partido e sindicato no pós-guerra. São Paulo: Editora Página Aberta, 1995, p. 7.

18 Dentre as principais queixas e reivindicações postuladas nas greves entre 1916 e 1970, os temas relativos a relações de trabalho aparecem como a segunda com mais registros, ficando atrás apenas de questões salariais. Nas relações de trabalho, estão compreendidos abusos e demissões, sistemas de multas, cumprimento de acordos, convênios e contratos. Cf.: PIZARRO, 1978, p. 36. 
ranhuras das tábuas. Eu fiquei 20 dias embaixo da neve em 1941, 20 dias em um acampamento esmagado pela neve. ${ }^{19}$

As condições de vida e a exploração me foram relatadas por Carlos Massalin no depoimento em que traçou com detalhes registros da experiência vivida com seu pai no início dos anos de 1950 no norte mineiro. São elementos que conformaram as experiências transmitidas entre as gerações de trabalhadores e levadas ao longo do processo de proletarização:

Meu pai era operário de um acampamento mineiro, um acampamento
mineiro de cobre de uma firma norte-americana, em Chuquicamata, que
nessa época era a maior mina de cobre do mundo a céu aberto [...] Era
uma mina onde não pagavam em dinheiro, só em [19]58 começaram
a pagar em dinheiro. Existia um sistema de pulpería: a companhia dis-
punha a casa, ou seja, o povoado era a companhia, e havia uma pulpe-
ría, e davam um cartão aos trabalhadores em que podiam retirar arroz,
açúcar e pão. Não havia comércio no acampamento mineiro. E havia
frutas, por exemplo, nós conhecíamos a laranja, a maçã e a banana. Es-
sas coisas levavam. E verduras como alface, acelga era assim bastante
limitado. O povoado estava dividido em dois: uma parte que era o acam-
pamento americano e outra parte que era acampamento operário. No
acampamento americano não havia só norte-americanos, mas também
mexicanos. Era todo o pessoal que era chefe, que lá chamavam roloro,
porque a eles pagavam diretamente em dólares; e tinha um sistema de
pulpería também, mas sem cartão, ou seja, você podia comprar direta-
mente. [...] Vivíamos em condições bastante precárias no acampamen-
to, tínhamos dois cômodos..$^{20}$

Além das condições precárias em que viviam os trabalhadores, o cotidiano era marcado pelas duras relações hierárquicas. Em muitas empresas, o controle patronal estava assegurado pela combinação paternalismo e repressão. Os depoimentos que coletamos revelam a recorrência de um modelo autoritário nas relações trabalhistas que perpassaram diferentes gerações de trabalhadores. Por meio das entrevistas e das fontes documentais, observamos a recorrência dessas práticas e as mudanças que se deram no comportamento político dos trabalhadores nas décadas seguintes, entre os anos de 1950 e 1970.

Guillermo Orrego, operário na empresa multinacional de telefonia, ITT, a partir do final da década de 1960, relata a prática autoritária nas décadas anteriores vivenciadas por seu pai:

Meu pai me contava de um gringo que era o gerente geral [da ITT] nesse tempo. Quando levavam a carta de reivindicações, ele a tomava, e as folhas ele jogava no lixo, assim, de insolentes os gringos. ${ }^{21}$

Hugo Valenzuela, operário da industria têxtil Sumar, nos relatou expressões dessas práticas exercidas tanto pela figura do patrão, num modelo autoritário e paternalista, em que uma das características era a presença do empresário no chão de fábrica, quanto dos chefes de seção, no período de transição para um novo tipo de relação, com a transmissão da autoridade para uma nova figura que exercia o controle do trabalho:

19 Em um depoimento emocionado, Inocente citou o recente acidente de trabalho ocorrido com mineiros chilenos, que teve repercussão mundial, dizendo-se identificado com aquela situação. Depoimento de Inocente Santo à autora, Santiago do Chile, 22 de outubro de 2011. Tradução minha.

20 Depoimento de Carlos Cortez Massalin à autora. Santiago, 04 de junho de 2009. Tradução minha.

21 Depoimento de Guillermo Orrego à autora, Santiago do Chile, 18 de junho de 2009. Tradução minha. 
O patrão era o dono da Sumar, Sr. Guillermo Sumar. Era um tipo déspota terrível; despediu um companheiro por ser feio. Um dia chegou e disse: "o que este feio faz aquí?" Por ser feio! Depois, quando nós tomamos a fábrica, fomos buscar o companheiro e o reingressamos à fábrica. Olha, o companheiro Espinoza, eu me lembro bem porque foi uma pena terrível o que ocorreu, um trauma forte que ele provocou a este companheiro.

[... ] havia muito abuso por parte dos chefes [... ele que andava com o açoite aí para fazer produzir, era com ele que tínhamos mais conflitos. No entanto, eram pequenos conflitos porque entrávamos para trabaIhar como ovelhas, íamos buscar o salário que nos permitisse viver e nada mais.

M: Que tipo de conflitos?

Basicamente eram os de produção, de dizer "quanto você produz, está produzindo menos", e, por exemplo, não podíamos ir ao banheiro duas vezes no dia, uma só vez, só. E se fosse pela segunda vez já ficava na lista ruim, digamos, na lista negra, como se enrolasse para não trabalhar. ${ }^{22}$

Fora da fábrica, outros fatores incidiam diretamente sobre a organização dos trabalhadores, como as conjunturas políticas. No governo de Gabriel González Videla, com a Lei de Defesa Permanente da Democracia, deu-se a cassação dos direitos políticos dos comunistas, em 1946, com a qual militantes políticos e dirigentes sindicais sequer conseguiam encontrar postos de trabalho, como nos relataram José Tohá e Inocente Santo.23

Vale citar, por exemplo, o caso da empresa Montero, presente nos registros da Direção do Trabalho. Ocorrido em 1965, outra conjuntura de acirramento político, com forte organização política e sindical, os patrões temiam ainda mais a proximidade das lideranças sindicais com os demais operários. A denúncia registrada indica que o empregador teria obrigado mulheres e empregados a não aderirem ao novo sindicato formado na empresa e retaliado os dirigentes, encaminhando-os a postos que não correspondiam ao seu trabalho, como arrumar caixas no depósito.

O empresário alegava que, após percorrer a empresa, descobriu que lá havia se formado uma espécie de "escritório de contra espionagem do governo" e que um dos dirigentes sindicais havia sido enviado pelo Partido Socialista para perturbar a empresa. Após negociações com a presença de inspetor do trabalho, ele afirmou que reintegraria os sindicalistas, mas em outros postos, para "evitar que mantivessem contato com os demais do setor". Um dos dirigentes foi encaminhado à cidade de Arica, onde sequer a empresa tinha filiais. Segundo a denúncia, o empregador tinha um acordo com o subsecretário do trabalho. ${ }^{24}$

Além do férreo controle exercido sobre a produção, portanto, a circulação de ideias era vigiada, e a única forma de representação tolerada era o sindicato "apatronado", como destaca Winn, a respeito da fábrica Yarur. Sob esse rígido sistema de controle, o desvio das normas de lealdade incondicional era informado pelos delatores, chamados "sapos", e castigado com transferência a seções indesejáveis, suspensões ou demissões, como relatamos acima.

22 Depoimento de Hugo Valenzuela à autora, Santiago, 10 de junho de 2009.

23 Dependendo fortemente do financiamento norte-americano num contexto de Guerra Fria, o apoio dos comunistas às greves contra a política do governo e as permanentes críticas feitas à relação do Chile com os Estados Unidos proporcionaram ao presidente González Videla a justificativa necessária ao rompimento com os comunistas. Para conseguir conter a pressão do PC e a agitação operária, apoiada pelos comunistas, o governo decretou, em 1948, a Lei de Defesa da Democracia, proscrevendo o Partido Comunista e atingindo diretamente os direitos e liberdades sindicais. José Tohá relatou, ainda, que passou a ser encaminhado pela empresa a diferentes postos de trabalho em diversas cidades.

24 Ministerio del Trabajo. Subsecretaria del Trabajo. Acta. Santiago, 13 de agosto de 1965. 
Na entrevista concedida para esta pesquisa, José Gomez, operário que ingressou na Têxtil Yarur no ano de 1956, relatou os obstáculos encontrados para a obtenção de pequenos direitos dentro da empresa, devido à inexistência de um sindicato, à autoridade exercida pelos chefes e à dificuldade de acesso ao patrão. O operário relatou também a prática de um ritual de juramento de fidelidade ao patrão, que ficou cristalizada na sua memória:

Quando eu cheguei, puseram um púlpito, onde se confessa aos padres, aí colocaram um pirata [caveira] para confessar à pessoa que nunca se ia levantar contra a empresa [...] um punhal assim [...] para jurar ali que nunca íamos estar contra a empresa. [...] Era um costume que tinha o empresário para que o trabalhador nunca formasse um sindicato [...] você tinha que jurar que nunca ia fazer nada. ${ }^{25}$

Não obstante a forte vigilância, o sindicato industrial da Têxtil Yarur nasceu das conversas informais entre os operários, entre os quais, simpatizantes e militantes de esquerda. Questionado sobre perseguições aos operários que estavam formando o sindicato na fábrica Yarur, Gomez declarou a existência de capatazes armados na empresa para intimidá-los. O resultado não só foi infrutífero, como o movimento dos trabalhadores da indústria Yarur veio a se tornar um símbolo das lutas operárias durante a Unidade Popular.

Em grande parte dos depoimentos coletados, os trabalhadores relataram as dificuldades encontradas para a obtenção de conquistas em função das relações estabelecidas entre os sindicatos ou comitês de fábrica e os patrões, evidenciando a permanência do controle exercido pela empresa, mesmo depois da regulamentação do Código Trabalhista. Isso contribuiu para gerar os denominados sindicatos "apatronados". A aceitação e a introjeção das relações paternalistas e de legitimação desse controle por parte de alguns trabalhadores, gerando relações de confiança entre patrão e operário, consequentemente, dificultavam a criação de órgãos representativos com maior liberdade dentro da empresa, como nos relatou Hugo Valenzuela:

Quando eu entrei [na fábrica] não havia sindicato ainda, então tinha uma espécie de representação sindical, e esta representação sindical tinha como cabeça um rapaz que se chamava Manríquez, que era do Patria y Libertad, que era como a UDI de agora, uma coisa assim, um movimento de extrema direita. Então, havia delegados por seções e esses delegados formavam depois uma espécie de assembleia geral, que era presidida pelo Manríquez. Então, quando conseguiam fazer alguma petição de tipo econômico, se fazia o que o Manríquez dizia, o que Ihes dizia o patrão. Então, não havia muitas possibilidades de que os trabalhadores conseguissem suas reivindicações econômicas. Nós não tínhamos refeitório para almoçar, não tínhamos creche, não havia absolutamente nada. ${ }^{26}$

\section{A organização e a representatividade no cotidiano}

Sob forte controle e com essas contradições no interior da classe trabalhadora, foram diversos os problemas enfrentados pelos trabalhadores no cotidiano e as experiências compartilhadas. As mais diversas questões eram objeto de comentários

25 Depoimento de José Gomez à autora, Santiago do Chile, 23 de julho de 2010. Tradução minha

26 Depoimento de Hugo Valenzuela à autora. Santiago do Chile, 10 de junho de 2009. Tradução minha. 
durante as pequenas pausas nos corredores, no futebol e durante o horário das refeições, fosse nas calçadas ou em refeitórios, mesmo que com cautela, por receio de que os "sapos" os denunciassem à chefia.

As reações aos abusos e à exploração se deram na formação de organizações políticas, mas estiveram presentes também em pequenas ações cotidianas que envolviam sabotagem, enfrentamentos e atos de rebeldia. Hugo Valenzuela nos descreveu situações vivenciadas na fábrica têxtil Sumar, como a falta de liberdade para ir ao banheiro, as ações da figura autoritária do patrão e as dificuldades para reivindicar melhorias no local de trabalho, conforme já vimos. Como um exemplo das dificuldades cotidianas, ele citou a ausência de condições mínimas de alimentação no trabalho:

Nós não tínhamos um refeitório onde almoçar [...], não havia absolutamente nada. Inclusive, quando chegava a hora do almoço nos davam um sanduíche e uma bebida. Tínhamos que comer sentados no pátio, no chão. Eu me lembro que minha primeira experiência de... digamos... rebeldia nisso foi que nos deram um sanduíche em que o presunto estava estragado. Então, um companheiro parou e jogou o sanduíche na janela, e começou todo mundo a jogar os sanduíches até que se formou uma montanha de sanduíche. ${ }^{27}$

Segundo Gómez, em 1965, o gerente da indústria solicitou a intervenção de um representante da Direção do Trabalho devido a uma paralisação total realizada pelos operários, que exigiam a demissão do chefe de produção. Naquela ocasião, eles haviam decidido parar a produção por 15 minutos a cada hora como forma de advertência e protesto contra as atitudes arbitrárias e a contínua "falta de respeito" com os trabalhadores por parte deste chefe.

No processo registrado na Direção do Trabalho, o chefe de produção afirmava que naquela ocasião ele havia tido a necessidade de tomar medidas de organização interna, as quais teriam colocado fim a uma "série de abusos cometidos pelos operários". O argumento do chefe era de que, ao deixar de trabalhar na linha de produção com móveis, a indústria passou a se dedicar exclusivamente ao mobiliário de máquinas de costura. Assim, o trabalho teria se simplificado de tal forma que permitia controlar de forma mais efetiva a produtividade de cada operário, o que antes era praticamente impossível, dada a complexidade do trabalho que eles executavam. "Antes, eles podiam dissimular o trabalho. Agora não é possível, pela simplicidade dele". ${ }^{28}$

O controle exercido por chefes e capatazes sofria resistência por parte dos trabalhadores, e também não impediu o avanço da organização e as importantes conquistas dos trabalhadores, que englobavam desde a simples instalação de um refeitório até o cumprimento dos seus direitos trabalhistas. É o caso, por exemplo, da indústria Bata, que, mesmo com um discurso de harmonia social e compartiIhando da fidelidade de muitos dos seus operários, não deixou de registrar um extenso histórico de greves e ocupações da fábrica ao longo dos anos.

Hilda Tobar pode ser citada como um dos exemplos dos operários da indústria Bata que se recorda com gratidão da empresa, aponta críticas aos trabalhadores mais engajados, que para ela "sempre exigiam demais". Ao mesmo tempo, reconheceu que as conquistas foram obtidas com a luta e com a organização dos operários

27 Depoimento de Hugo Valenzuela à autora.

28 Dirección del Trabajo. Inspección Departamental del Trabajo de Arica. Ofício 2510, Libro 2- 31j, 29 de noviembre de 1965. 
e se lembrou com satisfação dos momentos de sociabilidade vivenciados nas conjunturas de greve, mostrando que também compartilhava de episódios de resistência à exploração:

\begin{abstract}
Eu participava porque eu gostava das greves. Eu adorava quando havia greves. Porque nos juntávamos todos, tínhamos um sindicato grande aqui, um edifício, aí nos juntávamos, saíamos pra pedir... eu adorava as greves. Todos os dias ter que ir trabalhar, já estava cansada. Então com a greve tirava a gente da responsabilidade de ir todos os dias. Nos juntávamos no sindicato e aí nos falavam se tinha aumentado ou se não tinha aumentado [o salário]

"- Ah, que pena, acabou o conflito [risos] Tem que voltar a trabalhar [...] Íamos pros sítios pedir batatas [...] Fazíamos ollas comunes. Levávamos um prato e nos davam comida, eram boas as comidas. Todos os comércios nos davam carne, os açougues... É que a Bata era Peñaflor [cidade], sem a Bata, Peñaflor não era nada". ${ }^{29}$
\end{abstract}

O trabalho de Flores sobre a fábrica Cristalerías Chile mostra as tensões presentes nas relações entre os trabalhadores, decorrentes da postura assumida por parte dos operários diante da resistência ou mobilização coletiva ou da sua posição no processo produtivo. ${ }^{30}$ Esse é o caso dos "companheiros capatazes", como estão denominados nos registros de uma assembleia no Livro Ata do sindicato industrial da empresa.

Tais "companheiros" teriam encaminhado uma reivindicação especial à gerência e solicitado a intervenção por parte do sindicato em prol do seu pedido. $O$ Sindicato recusou-se a agir por um acordo especial com aqueles que eram considerados "inimigos dos operários", responsáveis por "informar sobre a atuação dos próprios companheiros", levando à demissão de muitos. Outro caso muito significativo foi a recusa do sindicato em permitir o sepultamento de um capataz no mausoléu do sindicato. Ele era conhecido como "negrero", por gostar de manter sob seu controle os trabalhadores de uma seção no subterrâneo da fábrica. Desse mausoléu eram excluídos trabalhadores considerados pouco leais, indesejados ou aqueles que furavam greves.

Carlos Massalin, que em 1970 trabalhava em uma fábrica de explosivos, nos explicou com detalhes as dificuldades para a articulação dessa nova representatividade mediante relações hierárquicas desiguais entre mandos autoritários e trabaIhadores com pouca experiência em articulação política e com medo de enfrentar os patrões. O mais importante é observar que essa articulação se deu a partir da iniciativa própria dos operários e notar a importância da experiência vivida por Carlos na sua origem em um acampamento mineiro e nas atividades nas ocupações de terrenos, e na formação de acampamentos urbanos. Mas também que, mesmo com pouca ou nenhuma experiência em militância sindical, a prática cotidiana em pequenas ações de organização e articulação contribuía para essa nova etapa:

Na seção onde eu estava brigamos, digamos, por um bônus por produção, então, me tocou ir falar com mais 4 operários porque eu tinha um nível maior de manejo, se pode dizer, por minha história familiar, e pelo

29 Ollas comunes é a denominação dada às refeições coletivas organizadas pelos trabalhadores, especialmente em situações de greve, ocupações de empresas e de terrenos. Depoimento de Hilda Tobar à autora. Peñaflor, 31 de julho de 2010. Tradução minha.

30 FLORES, Jorge R. Cristaleros: Recuerdos de un siglo. Los trabajadores de Cristalerías de Chile, Sindicato N. 2 de Cristalerías de Chile, Programa de Economia de Trabajo (PET), Santiago, 1998, p. 69. 
fato da experiência de ter trabalhado nos acampamentos organizando as pessoas. Ganhamos esse prêmio da produção, então quando veio a eleição para o sindicato, eu nunca havia falado na assembleia; então, a seção onde eu trabalhava me propôs como candidato. [...] então tirei uma quantidade de votos importantes e fui eleito para a direção. [...] E uma das primeiras coisas que fizemos foi começar a reivindicar primeiro as condições de vida da gente. As pessoas estavam bastante assustadas, pela falta de experiência, por vir das províncias, digamos, se esconde, tem medo, tem menos habilidade. [...] Além disso, nós tínhamos como chefes somente militares retirados, o gerente era um tenente coronel retirado, o subgerente era um capitão de corveta retirado, os dois oficiais e todos os chefes de seções eram suboficiais [...] o gerente e o subgerente eram de direita. Então, o gerente exigia que se enquadrasse militarmente quando um ia falar com ele, e se tinha um acesso muito restrito à direção.

Então, num sábado, depois da hora extra, nos reunimos, a direção mais outras pessoas, que eram como os líderes naturais, os que sempre organizavam os jogos de futebol, os que faziam a coleta, digamos quando alguém estava doente, todo esse tipo de coisa. Nos demos um prazo de duas semanas para que cada um de nós conversasse na sua seção para saber qual era o problema que mais afetava às pessoas. Depois de 15 dias, quando voltamos a nos reunir o problema que mais preocupava as pessoas era o refeitório, a comida. ${ }^{31}$

Na Cristalerías Chile, a experiência parecida de rearticulação do sindicato se deu devido à tendência de concentração do poder entre os mesmos líderes sindicais, observada por jovens trabalhadores no início dos anos de 1960. Observa-se que o silêncio dos operários acanhados deixava o campo livre para "os que sabiam falar" decidirem os pontos de reivindicação e o curso das negociações. Essa posição era reforçada em casos de contatos pessoais de líderes sindicais com políticos e autoridades do trabalho. Se por um lado essa estrutura sindical não impedia desvios e excessos, por outro, a convivência cotidiana dos trabalhadores com suas lideranças e com os temas sindicais permitiam o questionamento ao seu funcionamento, bem como a sua rearticulação.

O que se pode concluir é que o sistema de relações trabalhistas, de fato, gerou grandes dificuldades para o desenvolvimento de um movimento operário grande e unificado, pela estrutura formada, pelo controle exercido por um sistema paternalista predominante, bem como pelos limites do controle estatal sobre os desmandos patronais. No entanto, tal estrutura encontrou os seus limites na extensão do controle que se poderia exercer sobre a geração de laços de solidariedade entre os trabalhadores, de uma identidade classista, de filiações ou simpatia política por projetos transformadores, que se forjaram a partir da sua experiência coletiva cotidiana. Elementos que num momento de mobilizações políticas diferenciadas no país eclodiram em práticas revolucionárias.

No mundo do trabalho, ao longo dos anos, ainda que os industriais preferissem contratar trabalhadores rurais recém-migrados e seus filhos, por se originarem de locais onde ainda prevaleciam relações paternalistas e forte controle social, contando, portanto, com uma suposta passividade e obediência, esses trabalhadores viviam em comunidades onde a natureza das interações sociais e da vizinhança transmitia, reforçava e consolidava um forte sentido de solidariedade e de identidade de classe. Alguns deles eram de cidades de província e levavam com

31 Depoimento de Carlos Cortez Massalin à autora. op. cit.Tradução minha. 
eles as visões de mundo do centro mineiro do norte e de Antofagasta, das minas centrais de carvão, da cidade industrial de Concepción, ou dos portos centrais de Valparaíso ou San Antonio, os quais têm suas tradições de luta. Massalin, cujo pai foi sindicalista no setor mineiro, é parte dessa trajetória:

[...] Meu pai sempre conversou muito, ele nos explicava porque tinha que estudar, que os patrões não pagavam o que correspondia. Como todo mundo trabalha no mineral, quando estavam em greve, não é como na cidade, que se um está em greve um tio, um primo, um amigo pode ajudar. Lá, todos estavam em greve. Então, a gente dependia da solidariedade de outras minas, como El Teniente, Potrerillos, que nesse sentido havia muita solidariedade. Nos chegava o açúcar, a farinha [...].32

Entre os trabalhadores urbanos, a experiência de vida na mesma comunidade contribui para o compartilhamento de um mesmo modo de vida, de pensamento, para o reconhecimento de interesses em comum e da oposição de classes, ao identificar nas suas dificuldades a ausência da garantia de direitos básicos e os privilégios garantidos a poucos na cidade. Os valores vividos, surgidos em vínculo com a vida material e com as relações materiais, que iam forjando as suas ideias. ${ }^{33}$ Citando como exemplo a población em San Miguel, a "comuna roja", Winn corrobora a importância da sociabilidade na comunidade de trabalhadores:

\begin{abstract}
A linguagem e a política de classe os cercavam, como o hábito da solidariedade e a tradição de luta. Em geral, a influência da escola e da igreja era menos importante que as da família e dos amigos. As expectativas dos adultos e as interações com grupos pares reafirmavam um forte sentido de identidade de classe, e a experiência dos menores com o mundo fora da población freqüentemente corroborava a lição de que o Chile era uma sociedade de classes. Para a maioria, a consciência de classe trabalhadora começava em casa. Eram os familiares, amigos e vizinhos que formavam suas visões iniciais da sociedade chilena e seu lugar dentro dela. ${ }^{34}$
\end{abstract}

Acertadamente, Borón indica um dos fatores que contribuem para essa socialização dos trabalhadores dentro de uma "tradição proletária". ${ }^{5}$ Para ele, a rigidez da estrutura de classes na sociedade chilena e suas baixas taxas de mobilidade social fizeram com que várias gerações de operários vivessem em uma situação de classe homogênea e relativamente "isolada", de forma que crescem e se socializam dentro dessa tradição na qual a ideologia de esquerda constituiu um dos elementos da sua identidade e da orientação das suas lutas.

Desde a crise das atividades salitreiras gerada pela Grande Depressão, o mercado de trabalho do centro do país recebeu um significativo número de operários que reinverteram a direção do processo migratório, que antes era do campo, para as minas. Além dos trabalhadores rurais, boa parte desse contingente foi absorvido pelo crescimento industrial e, desse modo, a experiência de organização e de luta destes setores do proletariado chileno, composto de mineiros, que detinha o

32 Depoimento de Carlos Cortéz Massalin à autora. op. cit. Tradução minha.

33 THOMPSON, E. P. A Miséria da Teoria ou um planetário de erros: uma crítica ao pensamento de Althusser. Tradução Waltensir Dutra. Rio de Janeiro: Zahar Editores, 1981, p. 194.

34 WINN, Peter. Tejedores de la revolución. Los trabajadores de Yarur y la vía chilena al socialismo. Colección Movimientos Sociales. Traducción de Verónica Huerta y Paula Salazar. Santiago: LOM Ediciones, 2004, p. 126. Tradução minha.

35 BORÓN, Atilio. Notas sobre las raíces histórico-estruturales de la movilización política en Chile. Foro internacional, vol. XVI, n.1, julio-septiembre 1975, p. 111. 
maior contingente de filiação sindical — artesãos, portuários, núcleos de operários - se transmitiu ao longo do processo de constituição dessa moderna classe operária industrial. ${ }^{36}$

Os depoimentos que citamos aqui denotam uma conjuntura na qual jovens trabalhadores na época, animados pelas mudanças no cenário político nacional, lançaram-se à ação sindical. Ainda que, em geral, eles retratem processos de formação de novas organizações ocorridos entre as décadas de 1960 e 1970, o desenvolvimento do movimento operário se deu ao longo das décadas, sofrendo fluxos e refluxos, de acordo com as condições de trabalho, as conjunturas políticas, as ações do Estado e o autoritarismo patronal.

As experiências cotidianas relatadas pelos entrevistados demonstram também a permeabilidade do sistema de relações trabalhistas gerado ao longo dos anos, no qual a partir da sociabilidade intensa nos processos de greve, como as ollas comunes, assembleias, piquetes, campeonatos de futebol e, principalmente, nas relações no chão de fábrica, articulavam-se ideias e estratégias para alcançar melhor representatividade.

É importante observar na constituição do movimento sindical chileno a configuração de um sistema com níveis diferenciados de representação que se caracterizaram quase como estruturas distintas. O movimento operário se constituiu de pequenos sindicatos industriais e de comitês sindicais de representação dos trabalhadores das pequenas empresas que não podiam organizar-se em sindicatos, ou seja, composição muito diferente da organização mais ampla, que gerou uma estrutura hierárquica verticalizada, gerida por lideranças políticas que acabaram se distanciando do cotidiano operário. Essa estrutura está representada na Central Única dos Trabalhadores, a partir da sua formação, em 1957.37

De fato, ao longo dos anos, essa configuração do movimento articulado em pequenos e numerosos núcleos de representação gerou dificuldades ao movimento operário, no sentido do exercício da pressão política sobre o Estado e sobre o empresariado. Por outro lado, além de impedir o desenvolvimento de uma estrutura sindical burocrática, essa conformação se configurou como um importante espaço para o aprendizado organizativo e político dos trabalhadores, na formação e no fortalecimento de laços de solidariedade, na capacidade de organização e no poder de mobilização numa dinâmica política diferenciada como o processo da Unidade Popular.

Essa formação acabou por configurar sistemas legítimos de representação, uma vez que os líderes desses núcleos seguiam nas suas atividades fabris, em contato com os demais trabalhadores e com os problemas do cotidiano operário. Até o ano de 1965, por exemplo, os dirigentes sindicais não deveriam receber compensações mensais pelos soldos perdidos no desempenho dos seus cargos sindicais,

36 Numa crise do setor registrada no início dos anos de 1920, milhares de trabalhadores eram enviados a albergues na cidade de Santiago. O convívio entre eles nesses locais permitiu uma sociabilidade e, com isso, a circulação de ideias políticas e articulações, que eram registradas pelas autoridades locais como motivo de preocupação pelo atentado à ordem que isso representava.

37 Representatividade sindical da indústria manufatureira ao final da década de 1960: cálculos com base no número total de trabalhadores industriais, pouco mais de 30\%; baseado unicamente nas empresas que empregavam dez ou mais trabalhadores, obtém-se um nível de 60\%; mas se considerar somente as fábricas que tinham 25 ou mais trabalhadores - o mínimo legal para formar um sindicato - o nível de sindicalização atingia 70\%. Fábricas que empregavam entre 10 e 14 trabalhadores só podiam formar "comitês" sindicais, aos quais só era permitido cumprir algumas funções; estes tinham menos propensão a formar sindicatos. No entanto, esses comitês apresentavam um alto grau de mobilização por reivindicações. Dados do número de reivindicações no ano de 1964 apontam que do total de 525 demandas dos sindicatos industriais, 297 foram apresentadas por comitês sindicais. Cf.: ANGELL, op. cit., 1974, p. 56. 
e se esperava, de fato, que trabalhassem turnos completos em seus empregos normais. Assim, teve a vantagem de reduzir a distância entre os dirigentes sindicais e as bases, transformando os dirigentes em reconhecidas lideranças dos trabalhadores. Havia exceções somente nos sindicatos onde conseguiam um acordo com os patrões e graças a estatutos especiais, como os dos sindicatos da marinha mercante e os dos trabalhadores do cobre. ${ }^{38}$

É possível afirmar que o efeito dessa estrutura foi aumentar a importância relativa da atração que exerce o compromisso político como motivação para ocupar cargos sindicais, uma vez que não havia qualquer outro tipo de atrativo, como financeiro ou de poder. $O$ anseio por conquistas de melhorias e as limitações sofridas diante do controle patronal foram os aspectos mais citados pelos trabalhadores como motivação para a formação de órgãos representativos nas entrevistas realizadas.

Baseado em outros estudos acerca do movimento sindical, Angell afirma que os sindicatos médios, com 100 a 200 membros, tamanho frequente entre os sindicatos chilenos, detinham participação mais ativa. Nesse porte de fábrica, especialmente onde a sindicalização era obrigatória, as circunstâncias favoreciam uma relação estreita entre dirigentes sindicais e dirigidos, bem como a discussão dos assuntos entre um número muito elevado de membros.

Mas, nas pequenas e médias empresas, eles sofreram maiores dificuldades na defesa das suas reivindicações perante os patrões. Isso se traduziu numa relativa fragilidade dos sindicatos, os quais, para suprir suas deficiências, buscaram apoio em diferentes frentes no sentido de exigir solução da parte das autoridades e de vencer o conflito frente aos patrões. Essas reivindicações eram encaminhadas a outros sindicatos operários em geral, às federações operárias, à CUT, às organizações estudantis, às entidades de bairro e aos partidos políticos. Normalmente, a ajuda que os grevistas recebiam era econômica, mas também organizativa, moral, e se expressava em paralisações de solidariedade, em trâmites, em atendimento profissional gratuito, em ocupações, em boicotes etc. ${ }^{39}$

No exercício da pressão política para a resolução de conflitos e para avançar nos trâmites burocráticos, nota-se nos registros da Direção do Trabalho importante intervenção parlamentar. Em geral, são ofícios encaminhados por deputados e senadores ao Ministério do Trabalho e às direções regionais do trabalho, denunciando os problemas enfrentados pelos trabalhadores e solicitando a mediação dos órgãos públicos. Os registros se referem a empresas de Santiago e de outras partes do país, como da região Norte. ${ }^{40}$ Por outro lado, os depoimentos que coletei fazem referência às práticas recorrentes nos movimentos grevistas, como as ollas comunes, as reuniões na sede sindical, e à importância do envolvimento da comunidade para a manutenção do protesto, o que também pode ser interpretada como uma forma de conquistar apoio e legitimidade entre a população local, outro aspecto fundamental que propiciou a articulação das lutas na década de 1970.

A autonomia dos sindicatos favorecia a autêntica participação, além do permanente contato para as discussões, conversas, realização de paralisações de protesto e piquetes, além da responsabilidade das lideranças diante dos companheiros

38 Em 1965, foi aprovada a emenda que dava o direito à compensação. Se a assembleia permitisse, os dirigentes recebiam salário e gastos desses fundos quando tinham que atender assuntos sindicais no horário de trabalho. Cf.: ANGELL, op. cit., 1974, p. 71.

39 BARRERA, M., op. cit, 1971, p. 150.

40 Dirección del Trabajo, Oficios, Volumen 2350, 15 de octubre de 1965. Dentre as denúncias registradas, grande parte refere-se a descumprimento da lei quanto a pagamento de salários, perseguição a sindicalistas, demissões injustificadas, abusos e intransigência patronal. 
no cotidiano. O sindicato local de trabalhadores de uma só fábrica se mostrou bastante democrático dentro do movimento sindical.

No Chile, o tamanho reduzido dos sindicatos, sua debilidade financeira e as restrições legais ao pagamento dos dirigentes inibiram o desenvolvimento de uma direção burocrática institucionalizada que em outras partes substitui com frequência a democracia por uma oligarquia trabalhista. Dessa forma, os dirigentes sindicais chilenos raras vezes sentiam uma diferença de categoria entre eles e as bases, e voltavam a tomar a posição de trabalhadores comuns sem nenhum esforço aparente, nem econômico nem de outra natureza. Essa característica mostrou-se extremamente importante para manter a participação e a representatividade nos sindicatos, uma vez que eram "dirigentes trabalhadores", ou seja, o dirigente era "só mais um trabalhador".

\section{Do sindicato ao Cordão Industrial}

Os Cordões Industriais, que eram setores industriais que congregavam fábricas de diferentes ramos produtivos, estavam instalados em áreas de fácil acesso, ligados por vias expressas, para facilitar tanto a chegada de matéria-prima quanto o escoamento da produção..$^{41} \mathrm{~A}$ importância dessas áreas durante o governo da Unidade Popular (UP) esteve na articulação política dos sindicatos das empresas estabelecidas nesses locais.

Em geral, o estabelecimento de relações sociais distintas das vivenciadas no sistema produtivo, com a busca de formas alternativas de controle da produção e de defesa política das suas organizações estiveram entre os objetivos dos Cordões Industriais. Tal articulação se deu no contexto da chamada crise de outubro, em 1972, visando principalmente à mobilização de ações conjuntas para a manutenção da produção sob o controle dos trabalhadores e a sua organização política em defesa do governo socialista, mantendo o permanente debate entre os líderes sindicais locais. Muitas das suas ações consistiam no intercâmbio de mercadorias e de peças, na união de diferentes fábricas para a venda de produtos nas poblaciones, em feiras populares e em atos de solidariedade, como na ação conjunta em tomas (ocupações), e com pobladores. ${ }^{42}$

Tais ações dos Cordões Industriais foram empreendidas no episódio do desabastecimento do país e demonstraram a importância da extensão da organização dos trabalhadores. Nesta crise desencadeada por uma greve patronal que visava ao boicote ao projeto socialista, a maioria do comércio permanecia fechada, levando diversas organizações comunitárias e sindicais de diferentes comunas a se unir para organizar a distribuição e a venda de produtos à população. Especialmente as indústrias da Área Social, que era o setor estatizado da economia, e os sindicatos operários das fábricas ocupadas compravam produtos elaborados entre as empresas, trocavam matérias-primas e vendiam produtos a preços oficiais em feiras em diversos bairros de Santiago. ${ }^{43} \mathrm{O}$ aumento da produção em alguns setores da Área Social levantou a preocupação com o destino do excedente produzido.

41 Definição dada por Aldo Aguillar, em depoimento a Elisa Borges. In: BORGES. Elisa de Campos. ;Con la Unidad Popular ahora somos Gobierno! Experiência dos Cordones Industriales no Chile de Allende. Tese (Doutorado em História Social). Universidade Federal Fluminense, 2011, $250 \mathrm{f}$.

42 Poblaciones são os bairros da periferia do país, e os pobladores são os seus habitantes.

43 No Chile, os sindicatos eram diferenciados entre aqueles representantes dos operários, setor de trabalho "manual", denominado sindicato industrial, e aqueles dos denominados empregados, que eram de serviços, trabalho considerado "intelectual". 
A organização das feiras populares se deu por meio da articulação dos sindicatos das fábricas nos diferentes Cordões Industriais. E cada vez mais empresas eram convocadas para participar dessa ação que abastecia os bairros, ao mesmo tempo em que garantia os rendimentos das empresas que não conseguiam vender normalmente devido à paralisação do comércio, e evitavam o abastecimento do mercado negro.

Nessa etapa da mobilização, na qual os trabalhadores reorganizaram os processos de fabricação e de distribuição de bens de consumo, trabalhando autonomamente em instalações que não os pertenciam, constituía-se, além da inversão dos princípios jurídicos básicos do funcionamento do capitalismo, um mercado de solidariedade, uma vez que quem adquiria os produtos não se limitava a apoiar os operários materialmente, mas mostrava uma solidariedade mais profunda. ${ }^{44}$

O método que realmente ampliou a capacidade mobilizadora dos Cordões foi o das tomas de indústrias. Por meio das ocupações de fábricas, se enfraquecia a posição dos patrões dentro de suas próprias empresas e se potencializavam as coordenações de trabalhadores. Ao menor sinal de boicote da produção ou da distribuição de produtos pelos empresários, os trabalhadores se mobilizavam para assumir o controle da empresa. Nasceram, assim, os cordões de Vicuña Mackenna e Estación Central, em Santiago, e de Hualpencillo, em Concepción, em decorrência da paralisação de outubro. ${ }^{45}$

O caráter territorial dos Cordões incidia na própria organização dos setores industriais na cidade de Santiago, e essa característica possibilitou uma vinculação efetiva entre diferentes fábricas e destas com as poblaciones. Isso também facilitou a utilização estratégica da sua localização geográfica, já que muitos desses polos se encontravam em grandes avenidas de circulação chave para a entrada e saída da cidade de Santiago. Muitas vezes, suas ações consistiam na realização de barricadas, o que lhes outorgava o controle sobre o local e garantia maior poder de pressão sobre as autoridades. ${ }^{46}$

Se por um lado alguns trabalhadores afirmavam não ser o Cordão Industrial uma "coisa concreta", por se tratar mais de reuniões políticas dirigidas por líderes sindicais locais, demonstrando que havia muito o que se avançar na democratização da participação, por outro, os trabalhadores sabiam da sua existência, compreendiam o sentido daquela organização, conheciam as suas lideranças e destacaram as adesões generalizadas nas mobilizações e nos atos por eles organizados.

Nora Gomez, que no período era operária do setor eletrônico, afirmou na sua entrevista que, pela criação mais conservadora que recebeu, não entendia muito bem o processo político da época, mas que se recorda muito bem do papel dos Cordões na mobilização política dos trabalhadores:

Do cordão, o que eu me lembro era, por exemplo, se tinha uma manifestação, uma marcha e diziam "olha, os sindicatos do cordão Vicuña Mackenna tem que estar onde lhes corresponde... Plaza Italia". Lá iam todos, mas não os obrigavam, porque a maioria que queria ia. Nesse aspecto político eu me recordo, estavam lá. Também quando iam em

44 BERNARDO, João. Economia dos conflitos sociais. São Paulo: Cortez Editora, 1991, p. 337.

$45 \mathrm{Em}$ geral, as ocupações se davam como forma de enfrentamento às relações trabalhistas, de pressão para gerar a intervenção governamental na empresa, a sua passagem à área estatizada, e como forma de dar prosseguimento à produção quando os empresários e gestores paralisavam ou boicotavam o processo produtivo.

46 SОTO, Sandra Castillo. Cordones Industriales. Nuevas formas de sociabilidad obrera y organización política popular. Chile 1970-1973. Colección Historia Vital. Concepción: Ediciones Escaparate, 2009, p. 226. 
apoio, quando tinha alguma empresa de Vicuña Mackenna de qualquer ramo, não somente eletrônico, que estivesse em greve, se solidarizavam os sindicatos e iam ver seus trabalhadores, para apoiá-los na alimentação, e diziam "os trabalhadores em greve precisam fazer uma olla común”. Desse tipo de situações de solidariedade, eu me lembro sim. [...] A maioria, a maioria [participava] sim, porque eu acho que a maioria tinha noção política. 47

Ao mesmo tempo, é possível verificar os avanços e as realizações dessa organização no cotidiano e na prática social. Os Cordões, juntamente com outras organizações de bairros de Santiago, foram os responsáveis por organizar um novo sistema de relações comerciais para neutralizar os efeitos da crise sobre a população. Assim, se encarregaram do comércio, da distribuição, do transporte e da defesa das fábricas, adotando medidas como as que citamos acima, na utilização do caminhão da fábrica para transportar leite às poblaciones, na organização das feiras populares, no intercâmbio de produtos e de matérias-primas entre as fábricas, e na formação de comitês de defesa com pobladores e operários contra possíveis ataques.

Além do aspecto territorial, a característica da organização sindical operária foi um fator fundamental para a organização dos Cordões Industriais. Como foi destacado, o fato de o sindicato ser estruturado por empresa e contar com a presença diária dos seus dirigentes no cotidiano fabril permitiu que se consolidassem lideranças legítimas entre os trabalhadores. Ou seja, os sindicalistas seguiam compartilhando dos problemas cotidianos do ambiente de trabalho e eram reconhecidamente representantes, e isso se dava sem deixarem de ser mais um trabaIhador entre os demais, diferentemente do que representava a estrutura "lenta e burocrática" da CUT entre eles. ${ }^{48}$

Assim, o sentido de solidariedade, do reconhecimento do sindicato enquanto representante daquele núcleo de trabalhadores e de forte envolvimento no conflito político que se desenvolveu ao longo da organização sindical na fábrica se consolidava e permitia a sua ampliação para formas mais amplas. Isso fica evidente na declaração de Massalin a respeito do Cordão Pan Americana Norte:

[...] Agora o que acontece é que essa fábrica pequenininha de papeIão tem um conflito normal de reivindicações e o industrial que impõe que não, que não vai aceitar as reivindicações deles, e isso as pessoas levam para o cordão, e o cordão diz: "se não se resolve o problema da Papelera del Sur paramos tudo". E que significa parar tudo? Cortar territorialmente, essa era um pouco a graça do cordão. Ou seja, se havia um conflito no cordão, ao interromper o acesso de caminhões, não podia nem chegar matéria prima nem sair produtos. Eu acredito que aí é onde o cordão começa a ser muito mais político; se vai dizer "bom, aqui somos trabalhadores, somos um cordão, resolvemos juntos o problema da comida, mas também vamos resolver juntos o problema das condições de vida e de trabalho de cada uma das fábricas do setor". Isso permitiu para nós que nas fábricas menores que haviam se consolidasse o trabalho que havia, porque objetivamente tinham mais povo para resolver seus conflitos. Isso foi na paralisação de outubro de $72 .{ }^{49}$

Esse relato de Massalin demonstra a importância dos espaços de organização dos trabalhadores, como o Cordão Industrial, nos seus diferentes aspectos: na

47 Depoimento de Nora Gomez à autora. op. cit. Tradução minha.

48 Depoimento de Joaquin Abarzúa à autora. Santiago do Chile, 29 de junho de 2010.

49 Depoimento de Carlos Massalin à autora. op. cit. Tradução minha. 
intensidade com que se vivenciou a solidariedade entre os trabalhadores, uma vez que um conflito entre operários e patrões ocorridos em uma empresa se tornava um problema coletivo, de todos os trabalhadores da região; no caráter pedagógico, pois ações simples ou mais complexas, como um piquete nas fábricas e nas ruas, ou atos estratégicos de retenção ou de distribuição de produtos e matérias-primas exerciam a função do aprendizado e do aprofundamento da gestão da própria luta política; e mais um aprendizado político, na medida em que esses trabalhadores atuavam de maneira a relacionar a resolução de um conflito cotidiano com uma luta por um projeto transformador mais amplo.

Foi possível observar que nessa experiência o fortalecimento dos laços de solidariedade e a tentativa de estabelecimento de relações mais "horizontais" estiveram muito presentes entre os trabalhadores no âmbito fabril e entre os pobladores. Muitas dessas experiências já podiam ser observadas no âmbito do trabalho, quando as condições políticas Ihes pareceram favoráveis, o que já resultava em experiências anteriores de articulação política nesses Cordões antes do governo da Unidade Popular. Como afirma Elisa Borges, o governo popular funcionou como catalisador de novas práticas do movimento popular, na medida em que acabou por estimular novas pautas de reivindicação e novas formas de organização..$^{50}$

Essa experiência de articulação vivenciada entre os operários foi descrita por Joaquín Abarzúa:

[...] na rua San Joaquín [...] atravessava a outra rua que é a Avenida Vicuña Mackenna, que também está cheia de indústrias. Têm indústrias têxteis, indústrias metalúrgicas, eletrônicas. [...] Os sindicatos que funcionavam nestas indústrias tinham relação entre eles. Então, como tinha relação, se tinha uma greve, os outros apoiavam. E faziam esporte, campeonatos esportivos e de futebol entre várias empresas e compartilhavam... havia várias atividades em conjunto então. Os cordões se formaram em 1972, mas já tinham relação de vários anos entre os sindicatos, entre os operários, e além de muitos operários que viviam nas poblaciones vizinhas, como eu, que me criei nessa población, havia outro amigo, que nos criamos juntos, que também trabalhava nesta indústria ou trabalhava na outra. Então havia uma relação de muitos anos ligada à indústria, ligada ao sindicato, ligada à atividade social. ${ }^{51}$

A experiência política dos Cordões Industriais, impulsionada na conjuntura de crise de 1972, alavancou uma participação dos trabalhadores industriais para além do espaço e dos temas do trabalho. Desde o início do governo da UP, já havia questionamentos aos limites estreitos estabelecidos nos critérios de participação que levaram os trabalhadores a reagir com ações diretas para estender os seus espaços de atuação. A ofensiva da oposição e a crise dela gerada fez com que se ampliasse a percepção entre os trabalhadores de que eles podiam ser sujeitos ativos na proteção ao governo, e também no avanço das transformações. Por intermédio da ampliação da sua articulação e organização, foi possível que garantissem não só a manutenção da produção e da distribuição, além do abastecimento da população, como a mobilização política que deu sustentação ao governo durante o período de crise.

Os Cordões Industriais, que era a união territorial de vários sindicatos de uma zona industrial, tinham como núcleo uma ou algumas empresas ocupadas por seus

50 BORGES, op. cit.

51 Depoimento de Joaquin Abarzúa à autora. Santiago do Chile, 29 de junho de 2010. Tradução minha. 
trabalhadores, que na maioria dos casos reivindicavam a passagem à área estatizada, geralmente com o apoio de militantes de grandes empresas da área estatizada e de outras fábricas privadas. Essa organização foi fruto do trabalho dos sindicatos das fábricas, animados pelos setores mais jovens e radicalizados do movimento operário, especialmente as bases do PS, como em Cerrillos, Vicuña Mackenna e Conchalí.

Inegavelmente, na conjuntura de ofensiva da oposição social e política, enquanto se multiplicavam as ocupações de fábricas, de estradas, de órgãos públicos, muitos fundamentos da acumulação de capital e da propriedade privada dos meios de produção foram contestados. Especialmente, a tentativa de expandir as ações para fora da fábrica - a partir da percepção de que as ações da burguesia chilena afetavam o funcionamento de toda a estrutura do país, e de que era necessário exercer o controle para além da produção — dá indícios do desenvolvimento da consciência revolucionária da classe trabalhadora, ao desenvolver as formas radicais de luta em relações coletivistas e igualitárias.

O que se pode concluir é que, desde a crise de outubro, ocorreu uma viragem importante no processo político do país, não porque o confronto de classes foi deslocado do Estado para a sociedade civil, como afirma Marie Noelle Sarget ${ }^{52}$, mas porque se escancarou definitivamente uma luta de classes presente no cotidiano da sociedade chilena, só que numa conjuntura de clara disputa pela hegemonia, em confrontações também de violência. Esse contexto nos remete a uma clara expressão de identidade de classe, que envolve o compartilhamento de visões e interesses comuns, a solidariedade, o confronto com setores antagonistas e que pode, em certas situações como no contexto da Unidade Popular, incidir sobre a formação de um fenômeno revolucionário.

\section{O fim da autonomia?}

A partir dessa análise, é possível afirmar que os trabalhadores chilenos sempre buscaram formas de reagir à exploração e impuseram pressões aos capitalistas e ao Estado, e acabaram por desenvolver modelos diferenciados de ação política. A conquista dos direitos trabalhistas, das melhorias nas condições de trabalho e de políticas de bem-estar devem ser interpretadas, portanto, como resultados das pressões e das lutas dos trabalhadores. Do contrário, poderemos incorrer numa leitura que avalize essas transformações como ações benéficas de uma elite ilustrada empossada num Estado benfeitor ou manipulador, como se todos os problemas da sociedade chilena tivessem sido "resolvidos de um modo puramente técnico e sincrônico" e os movimentos populares fossem "os grandes ausentes do processo formal de construção e reconstrução do Estado", como interpreta o historiador Gabriel Salazar. ${ }^{53}$

Leitura muito semelhante faz Manuel Barrera, para quem, com o período de incorporação da classe operária à sociedade política e com o surgimento de "organizações sindicais mais funcionais para o conflito operário", o sentido da greve como rebelião ou motim desapareceu. ${ }^{54}$ Para ele, o Estado institucionalizou a organização

52 SARGET, Marie Noelle. Apud. GAUDICHAUD, Franck. Etude sur la dynamique du mouvement social urbain chilien. "Pouvoir populaire" et Cordons industriels durant le gouvernement de Salvador Allende (19701973) Volume I. Thèse pour obtenir le grade de Docteur en Science Politique, Université Paris VIII, St Denis, 2005, p. 716.

53 SALAZAR, G. op. cit., 2009, p. 21.

54 BARRERA, M. op. cit., 1971, p. 152. 
sindical de base, mas esse teria sido essencialmente o órgão de dominação da burguesia mineira e industrial, dos latifundiários e do capital estrangeiro.

O caráter das lutas operárias até a década de 1920 tinha estreita relação com a inexistência de canais institucionais para a resolução dos conflitos. Assim, o traço característico do movimento operário chileno era de independência em relação ao Estado, sendo denominado de sindicalismo revolucionário pela historiografia, certamente, muito em função da ausência de possibilidade de outros grupos sociais ocuparem espaços de representação institucional no contexto de hegemonia oligárquica que prevalecia no país. Verifica-se que, ao longo das décadas, as formas de organização operária e as influências políticas sobre elas foram se modificando, buscando novos mecanismos de luta e de mobilização, refletindo, principalmente, nas relações com a política partidária e institucional, mas sem abandonar suas práticas de mobilização cotidianas.

Conforme afirmei anteriormente, os trabalhadores atuavam seguindo a sua lógica prática do diálogo e do enfrentamento, refletindo a autonomia na sua organização. E nesse caso, as articulações sociais com os partidos de esquerda, com clara noção do seu objetivo político e de resistência aos opositores, e o fortalecimento dos seus laços de solidariedade em ações políticas conjuntas não deixam dúvidas quanto ao significado daquelas mobilizações.

O que procurei mostrar foi que as modificações institucionais se deram ao longo dos anos, sem que isso implicasse o fim das expressões de ações coletivas de resistência à opressão e à exploração, em reação a questões do cotidiano do trabalho ou na formação das suas organizações, dentre as quais, os sindicatos, que exerceram protagonismo nas interações sociais e nas influências políticas. Nesse processo, as diferentes formas de luta se complementaram e constituíram importantes recursos para as conquistas sociais ocorridas no país ao longo do século XX e para o questionamento ao sistema de poder social e político. Como afirma Thompson, jamais houve época em que a dialética da imposição da dominação e da resistência a essa imposição não fosse central no desenvolvimento histórico, e temos um movimento no qual a pressão vinda de baixo é contida no alto, absorvida, o que conduz a uma modificação da estrutura, seguida por uma nova pressão de baixo. ${ }^{55}$

Com a participação direta dos partidos populares no sistema político, a partir dos anos de 1930, os trabalhadores adquiriram maior poder de pressão sobre o Estado e passaram a adquirir maior espaço para a colocação das suas demandas. Iniciava-se nesse contexto uma nova relação da esquerda com o Estado e com o espaço institucional, o que influenciaria também a orientação dos movimentos populares nas décadas seguintes, que encarariam esse espaço como garantidor de direitos.

Nesse aspecto, acertadamente, Crisóstomo Pizarro afirma que o conflito coletivo, denominação dada aos acordos coletivos no Chile, pode ser considerado como um dos antecedentes fundamentais da evolução da sociedade chilena para formas mais democráticas, na medida em que garantiu o estabelecimento de regulações e de direitos nas relações de trabalho. ${ }^{56}$

O que se nota é que houve graves deficiências por parte do empresariado para assumir os custos da política de bem-estar que começou a ser propalada pelo Estado a partir dos anos de 1930, e muito do que se valorizou foram as formas de controle propiciadas pelo mesmo Estado. Este modulou uma estrutura sindical de forma a não permitir o fortalecimento do movimento operário e acabou configurando um

55 THOMPSON, E. P. As peculiaridades dos ingleses e outros artigos. Campinas: Ed. da Unicamp, 2001, p. 209. 56 PIZARRO, C. op. cit., 1978, p. 7. 
sistema que favorecia a cooptação e o controle dos dirigentes sindicais pelos patrões por muitos anos.

Mas, por outro lado, como vimos, isso acarretou a formação de lideranças legítimas, próximas dos trabalhadores e inseridas no cotidiano operário. Novas gerações, advindas do processo migratório de regiões de tradição no sindicalismo e nas lutas operárias, foram incorporadas a esse processo, contribuindo para o seu desenvolvimento. A partir das suas experiências cotidianas, que se vincularam às doutrinas partidárias, foram se gestando as possibilidades para uma mobilização diferenciada, como na formação dos chamados Cordões Industriais, ocorrida em 1972. Sendo assim, não se pode analisar a experiência da Unidade Popular sem considerar as ações das bases sociais do país nos seus próprios termos, que no enfrentamento com as bases do Estado capitalista trouxeram a faceta mais criativa daquele processo.

A disposição territorial das empresas e a permanência diária dos sindicalistas no cotidiano, que facilitava o diálogo e a vigilância constante dos trabalhadores, permitiram o desenvolvimento de uma sociabilidade entre os operários das diferentes fábricas, que trocavam informações sobre atividades diversas e sobre as greves. Com essa relação histórica, os atos de solidariedade deram o tom da sua articulação durante o governo da UP, especialmente a partir da paralisação de outubro.

A articulação dos Cordões Industriais resultou na manutenção do funcionamento da máquina produtiva, e numa organização de caráter político que fomentava o debate dos trabalhadores acerca do processo de mudanças e do papel a ser exercido por eles na transformação da sociedade chilena. Essa organização abriu caminho para o surgimento de propostas de novas formas de sociabilidade, e deu espaço para a criatividade operária, numa extensão das relações sociais para o exterior das empresas que atingiu novas formas e implicações superiores.

Evidentemente, num curto espaço de tempo como é o período analisado, entre a formação dessas novas lideranças sindicais, em meio a um contexto de radicalização política, e o fim do governo da UP, com o golpe militar de 1973, não poderíamos fazer qualquer afirmação sobre possíveis resultados futuros, como a verticalização e a burocratização do movimento operário. Por outro lado, não podemos afirmar que a "gestação do Estado Liberal" acarretou a perda de soberania dos trabalhadores ou a sua subordinação a doutrinas que os teria transformado em simples massa reivindicatória, como afirma o historiador Gabriel Salazar.

Uma vez que se observam no final do século XIX tradições radicais no nascente movimento operário de diferentes regiões do Chile, não é possível estabelecer rupturas ou cortes rígidos na postura desses trabalhadores frente às condições de exploração a que eram submetidos, utilizando como marco para a sua suposta subordinação a inserção desse movimento no processo de modernização do país e da sua vinculação com o movimento institucionalizado. Uma interpretação como essa parte do princípio de que a criação de uma legislação trabalhista e de que a adesão do movimento operário à luta institucional serviram como elementos de rompimento com toda uma tradição de luta e resistência. Ela não é capaz, portanto, de visualizar o movimento operário para além da estrutura burocrática constituída nas suas centrais, e deixa de valorizar também o protagonismo desses sujeitos nas suas práticas cotidianas de reação e de organização e na sua vinculação ativa com projetos transformadores.

As pequenas lutas cotidianas, as irrupções populares, como as tomas, a partir da década de 1930, as greves e motins que se intensificaram nos anos de 1950 
não podem ser encarados como surtos momentâneos de requisição de soberania dos trabalhadores frente a um Estado que os teria "encapsulado", mas, sim, como elementos de continuidade que conformavam uma tradição entre os trabalhadores do país, em lutas pelo reconhecimento dos seus direitos por parte das instituições e de tentativas de dar um novo ordenamento a elas. A identidade de classe desses trabalhadores e a sua tradição de luta foram se articulando também em torno da sua relação com os partidos, seus projetos e, consequentemente, com o Estado. Nesses movimentos está presente, sim, a vinculação de suas demandas com ideologias, mas a partir da sua própria lógica política expressada nas suas ações autônomas, numa relação de influência mútua, forjando novas demandas para transformar um Estado excludente.

Os Cordões Industriais traziam uma proposta mais democrática e diferente das estruturas institucionais verticalizadas. A sua articulação política significou uma ampliação de um modelo sindical de base, distinto da estrutura cutista, por exemplo, mas já existente entre os trabalhadores chilenos nos seus sindicatos. Teria sido a presença sindical vinculada à militância partidária como parte do cotidiano dos trabalhadores que teria possibilitado o debate permanente e a conformação rápida de uma organização de defesa política e de controle sobre a produção e distribuição em conjunto com um projeto político revolucionário. Assim, deu-se uma ampliação dessas formas de sociabilidade e de fazer política, já experimentadas de alguma forma. As ações de solidariedade, o interesse pelos assuntos políticos e sindicais e, principalmente, a legitimidade das lideranças entre os trabalhadores foram fundamentais para uma mobilização política diferenciada como a que se deu durante a Unidade Popular. 